DOI: $10.17951 / \mathrm{m} \cdot 2017.2 .9$

\begin{tabular}{lcr}
\hline & ANNALES \\
& UNIVERSITATIS MARIAE CURIE-SKŁODOWSKA & \\
LULLIN - POLONIA & \\
VECTIO M & 2017 \\
\hline
\end{tabular}

Marián Žabenský, Jana Hučková

Constantine the Philosopher University in Nitra

\title{
Slovaks in Serbia - Research in the Village of Vojlovica by Means of Multitemporal Analysis of Cultural Landscape Layers
}

\section{Introduction}

Vojlovica is one of the most southern Slovak enclaves in the Lower Land. Michalík ${ }^{1}, K_{\text {Kurpaš }}^{2}$, Čukan ${ }^{3}$ and others are doing the research on the Slovaks in the Lower Land. The site was inhabited by residents of nearby flooded village Marienfeld in the last quarter of the $19^{\text {th }}$ century. According to the latest census, there are 5015 inhabitants, of which 833 are Slovaks ${ }^{4}$. The main aim of the contribution is to point out the applicability of the method of landscape research: Multitemporal analysis of the transects of cultural landscape layers in the conditions of the research on Lower Land Slovaks, and to analyse and evaluate the research itself.

1 B. Michalík, Spolková činnost', [in:] Pivnica - kultúrne tradície Slovákov v Báčke, ed. J. Čukan, Slovenské vydavatel'ské centrum, Báčsky Petrovec 2010.

2 M. Kurpaš, Transformácie tradičnej architektúry, [in:] Silbaš - kultúrne tradície Slovákov v Báčke, ed. J. Čukan, Nový Sad 2013.

3 J. Čukan, Kontexty kultúrnych tradícii prímestskej obce v Banáte, „Kontexty kultúry a turizmu”, 2014, nr 2, p. 3-6.

4 M. Sklabinská, K. Mosnáková, Slováci v Srbsku z aspektu kultúry, Štamparija Stojkov, Nový Sad 2012, p. 372. 
2. What does the Lower Land mean?

The name "Lower Land" denotes the territory that is located south of the border of the Slovak Republic. There are areas in the south of Hungary, western Romania, northern Bulgaria, Serbia and Croatia ${ }^{5}$. We also include the areas of northern Hungary and northwest Romania, although they are not lowland. This fact does not fully correspond with the concept of the Lower Land, but the historical development and the ethnic processes that are going on here are contextually interconnected ${ }^{6}$. This territory is connected with the Slovak ethnic group and its

\section{Map 1}

Regions influenced by Slovak ethnic group

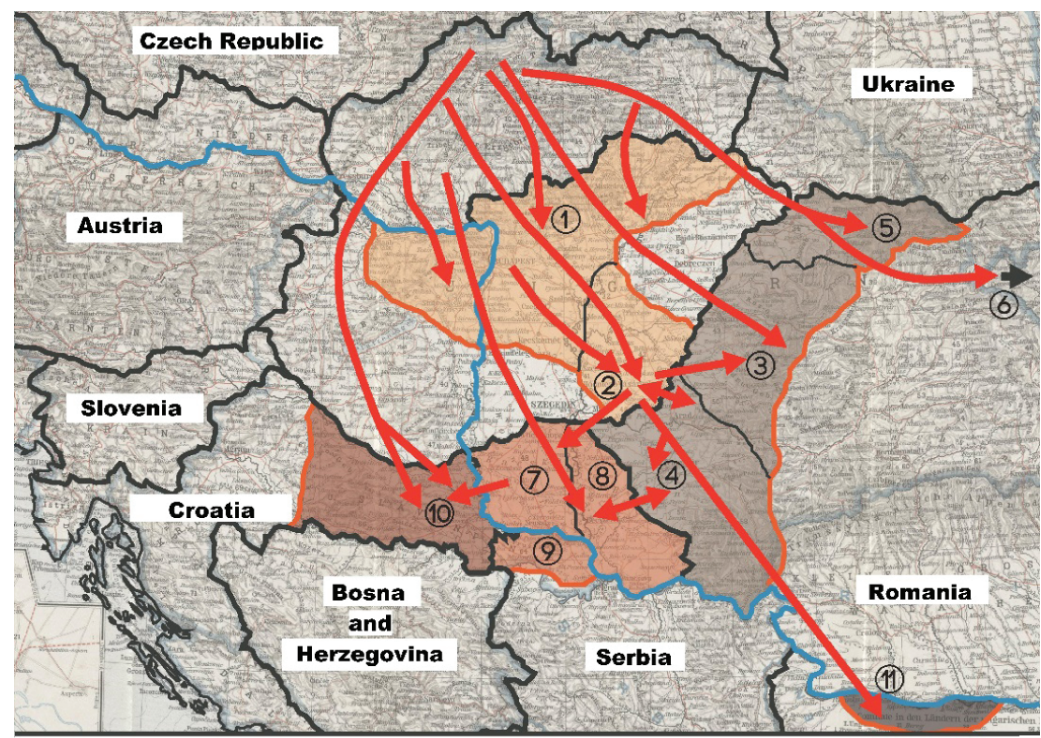

Areas affected by Slovak colonization

HUNGARY
1 - Northern and Central Hungary
2 - South Hungary
ROMANIA
3 - Bihor-Salaj region
4 - Arad-Banat region
5 - Satmar-Marmures region
6 - Bukovina region
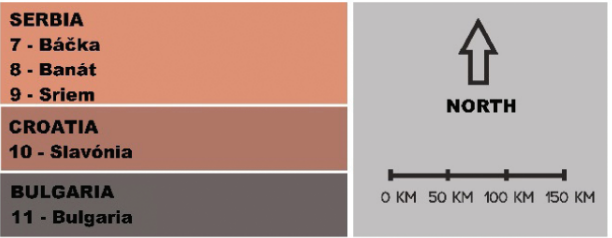

Source: Marián Žabenský (2016).

${ }^{5}$ J. Čukan, Dolnozemské reflexie na nerolnícke zamestnania, UKF Nitra, Nitra 2001, p. 9.

6 B. Michalík, Akulturačné procesy v prostredí dolnozemských Slovákov, Vydavatel'stvo Ivan Krasko, Nadlak 2015, p. 7. 
colonization took place in the period after the defeat of Turks in Vienna (1683) and their subsequent expulsion from Hungary. Many areas were ravaged and depopulated, and, thus, it prompted colonization ${ }^{7}$. Until the collapse of Hungary in 1918, the administrative units in present-day Slovakia were considered to be the upper-mountain regions, the Upper Land ${ }^{8}$. The Upper Land and the Lower Land are in such historical and geographical sense perceived as opposites.

The origins and the existence of each ethnic enclave and diaspora are accompanied by different causes, different complex of circumstances. Namely, we can identify specific cases when the decisive impulse for migrants to leave was their inability to subsist because of a small acreage of land, repeated years of crop failure and famines, desire for religious freedom, war conflicts, disagreement with current political processes and political persecution, disagreements in the family, escape from punishment, educational opportunities, and pursuit of adventure 9 . We can name many reasons, but not exhaustively. Variability is caused by different or even the same effects, but in a different geographic, socio-cultural, ethnic and confessional environment, with different history and collective memory, and, thus, they generate different response.

\section{Definition of the studied area}

The subject of the research is the village of Vojlovica and its immediate surroundings. As stated by Sklabinská and Mosnáková ${ }^{10}$, the village is a settlement of the town of Pančevo, located in Banát near the river Timis and is the centre of the south district of Banát. The studied territory was defined on the basis of several criteria. In the case of Vojlovica, it was necessary to take into account, among other things, historical events which significantly influenced the change of landscape structure. When defining the territory, it is essential to identify those points in the landscape that are definable in earlier time periods as well. These points were: the historic shooting range - Strelište, the former homestead of the Vojlovica monastery - Nadela, the junction of the present-day streets of July 7 and Joakim Vujič, or the mouth of the river Timis in the Danube.

\footnotetext{
7 J. Botík, Etnická história Slovenska, Vydavatel’ské družstvo, Bratislava 2007, p. 179.

8 M. Babiak, Anabáza, Vydavatel'stvo Ivan Krasko, Nadlak 2011, p. 9.

9 J. Botík, op. cit., p. 179.

10 M. Sklabinská, K. Mosnáková, op. cit., p. 372.
} 


\section{Map 2}

Definition of the studied area on the map from 1995 in scale 1:25 000

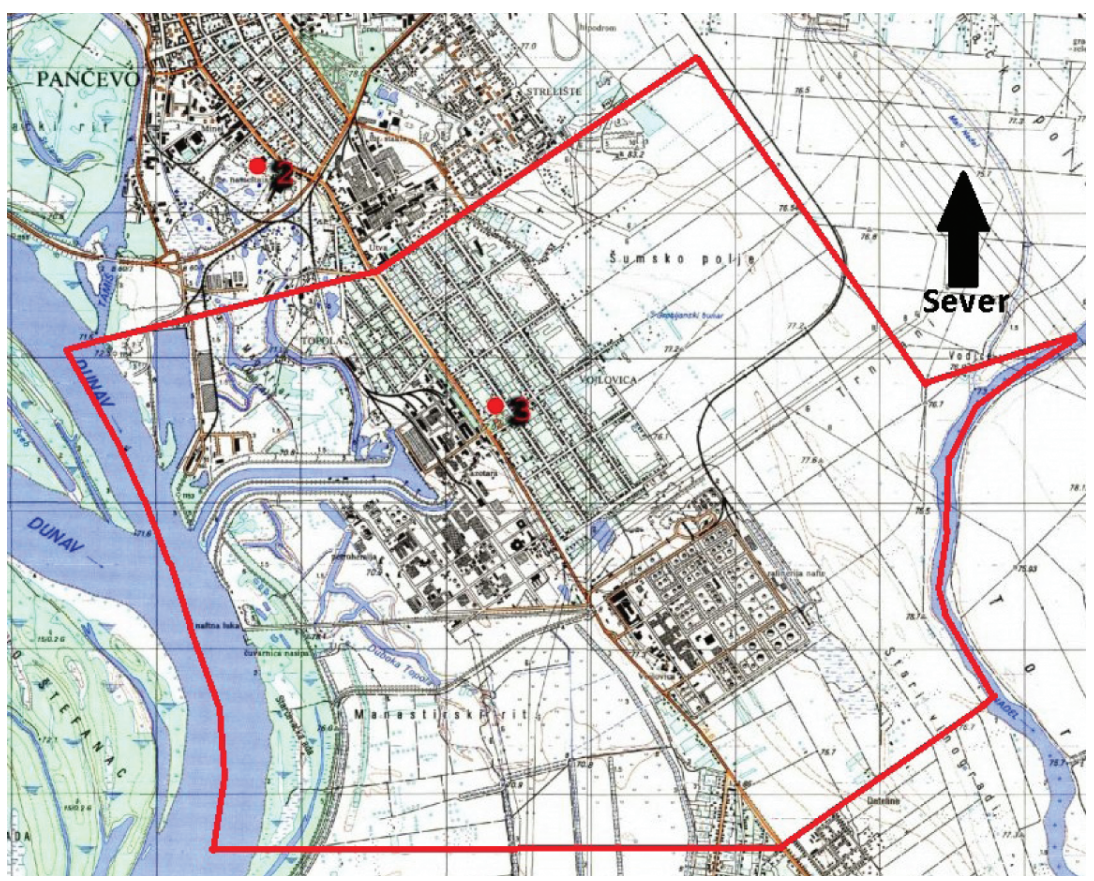

Source: elaborated by the author (2014).

\section{Methodology of research}

The research methodology consists of several follow-up steps aimed at obtaining relevant information on the geographical and cultural historical development of the area studied, with the emphasis on the subsequent identification of archetypes of the natural and cultural landscape. Several methods of research have been used to research the Vojlovica site.

Part of the applied methodology is land cover and land use with an emphasis on assessing classes of landscape use. The results are interpreted in the form of the historical development of the landscape, based on transects of the cultural landscape layers. Information about land development integrates the outputs of land cover and land use, and their connection is necessary to understand the context of landscape development in broader dimensions. The research focuses on the following land use classes: forests, water areas, permanent grassland, arable land, permanent crops and built-up areas. Land use and land cover are discussed at the theoretical-methodological or application level, among others by 
Bičík, Jeleček and Štěpánek ${ }^{11}$; Otahel ${ }^{12}$; Otahel’ et al. ${ }^{13} ;$ Pucherová $^{14}$; Petrovič ${ }^{15}$ and Muchová ${ }^{16}$. The most important methods used are the multi-temporal analysis of cultural landscape layer transects, based primarily on archaeological outputs, on the analysis of historical cartographic works and the field research. Research methodology consists of several key steps:

The first step is demarcation of the studied area, which is the territory of Vojlovica and its immediate surroundings. When selecting the area, it was necessary to take into account the geographical and historical aspects. The collection of available information resources represents the second phase of the research. The study of available literature and other sources (e.g. archaeological reports) focuses on selected issues (geography, culture, history) with accent on the area studied. An important source is the analysis of historical maps. In particular, the maps from the $2^{\text {nd }}$ military (Frantisek's) mapping (1806-1869), the $3^{\text {rd }}$ military mapping (1869-1887) ${ }^{17}$, the maps showing Serbia in 1995, and the maps of Google (2009-2014), based on aerial photography of the Republic of Serbia from the beginning of the $21^{\text {st }}$ century. Important sources of information are historical and contemporary photographs, which make it possible to identify and locate some landscape archetypes and historical landscape structures. In the third phase, based on the analysis of the above mentioned sources, a data synthesis will be created to develop a physical-geographic landscape characterization consisting of a geomorphological, climatological, hydrological, biogeographical and pedological part. The influence of the physical-geographical sphere on the development of culture and cultural innovations in the studied environment is also analysed. The fourth part represents the subsequent synthesis of the data expressed in the transects of the cultural landscape layers and their subsequent

${ }^{11}$ I. Bičík, L. Jeleček, V. Štěpánek, Land-use changes and their social driving forces in Czechia in the $19^{\text {th }}$ and $20^{\text {th }}$ centuries, [in:] Land Use Policy, ed. G. M. Robinson, Oxford, Amsterdam 2001, pp. 66-73.

${ }^{12}$ J. Otahel', Krajinná pokrývka Slovenska, VEDA, Bratislava 2001.

${ }^{13}$ J. Otahel', J. Feranec, T. Cebecauer, J. Pravda, K. Husár, Krajinná štruktúra v okrese Skalica: Hodnotenie zmien, diverzity a stability, „Geographia Slovaca”, 2004, nr 19, p. 123.

${ }^{14}$ Z. Pucherová, Vývoj využitia krajiny na rozhraní Zobora a Žitavskej pahorkatiny, UKF Nitra, Nitra 2004, p. 147.

${ }^{15}$ F. Petrovič, Vývoj krajiny v oblasti štálového osídlenia Pohronského Inovca a Tribeča, SAV, Bratislava 2005, p. 209.

${ }^{16}$ Z. Muchová, The potential of the landscape with dispersed settlement (case study Čadca town), [in:] Public recreation and landscape protection - with man hand in hand, ed. J. Fialková, D. Pernicová, Mendelova univerzita, Brno 2013, pp. 199-204.

${ }^{17}$ M. Boltižiar, B. Olah, Krajina a jej štruktúra (Mapovanie, zmeny, hodnotenie), FPV UKF, Nitra 2009, pp. 44-62. 
multi-temporal analysis ${ }^{18}$. The transect of cultural landscape layer represents a new method in the research on the cultural landscape, which was created by the modification of the method of cultural landscape layer profiles ${ }^{19}$.

The primary map constructions are based on the map data, and it is important to localize the points that can be defined in all such works and are then marked with letters (in case of the studied area - A to F). The transect illustrates the elements of the cultural landscape at the topical level (buildings) and the choric level (historical landscape structures, landscape utilization classes and their structure). The advantage is that the transect shows a land segment of about 600 meters wide, which helps to study spatial relationships. The subsequent multitemporal analysis is the basis for monitoring the development of these elements both in time and space (extinction of historical landscape structures, persistence of landscape archetypes, etc.). The advantage of this method is also a dynamic view of the development and the bonds of man (society) and the landscape. The transect is complemented by pictorial and symbolic map signs, and the new elements are marked in red in order to better visualize the dynamics of development. During the research, additional transects of cultural landscape layers were developed, which are not supported by map data. Their elaboration was carried out on the basis of analysis of archaeological findings (drawings, reports), historical written sources, testimonials of informants and visual materials. The procedure of Chrastina was used to compile them ${ }^{20}$. The current state of the studied territory is recorded through the field research, which represents the fifth phase. The data obtained serve to further research and to compare the development of historical landscape structures and current landscape structures. Existing archetypes are verified in the field, or new ones are examined, which are similarly retrospectively analysed as in the case of archetypes found on the maps. In the field research, archaeological non-destructive methods (e.g. surface survey), destructive methods (probe excavation in the sense of valid legislation in a given country) are applied and photographic material is produced to document the current status of landscape utilization, preserved historical landscape structures or landscape archetypes. Field research is needed to complement and

${ }^{18}$ The issues of multitemporal analysis are dealt with in the works of e.g. J. Otahel', J. Feranec, Výskum zmien krajinnej pokrývky pre poznanie vývoja krajiny, „Geographia Slovaca”, 1995, nr 10, pp. 187-190; J. Feranec, Prístupy k analýze viac časových údajov dial'kového prieskumu zeme, „Geografický časopis”, 1996, nr 48, pp. 3-11; P. Chrastina, Výskum krajiny (z aspektu historickej geografie a krajinnej archeológie), „Geografické štúdie”, 2010, nr 14, pp. 17-41ff.

${ }^{19}$ P. Chrastina, Profily kultúrnokrajinných vrstiev - metóda výskumu nielen industriálnej krajiny: na príklade mesta Nováky, „Historická geografie”, 2011, nr 37, pp. 167-183.

${ }^{20}$ P. Chrastina, Výskum krajiny..., op. cit., pp. 17-41. 
modify the elements of cultural landscape transects and to design a transect of landscape documenting the current state of the cultural landscape. The last step is to evaluate the development of the landscape and culture in intentions such as: defining the archetypes of natural and cultural landscapes, transforming the historical landscape structure into the present landscape structure, assessing the development of jobs, identifying traditional jobs, etc.

\section{Definition of transects of cultural landscape layers}

The process of identifying individual landscape segments took into account the possibilities of their application in all map materials. The transect AB begins in the space under the shooting-gallery (Strelište), as the historical and current shooting-gallery is well localized on all the maps. Point B is under the present Vodice chapel, formerly Manastirski hodaj - the homestead of a monastery (near

\section{Map 3}

The course of individual transects of the cultural landscape

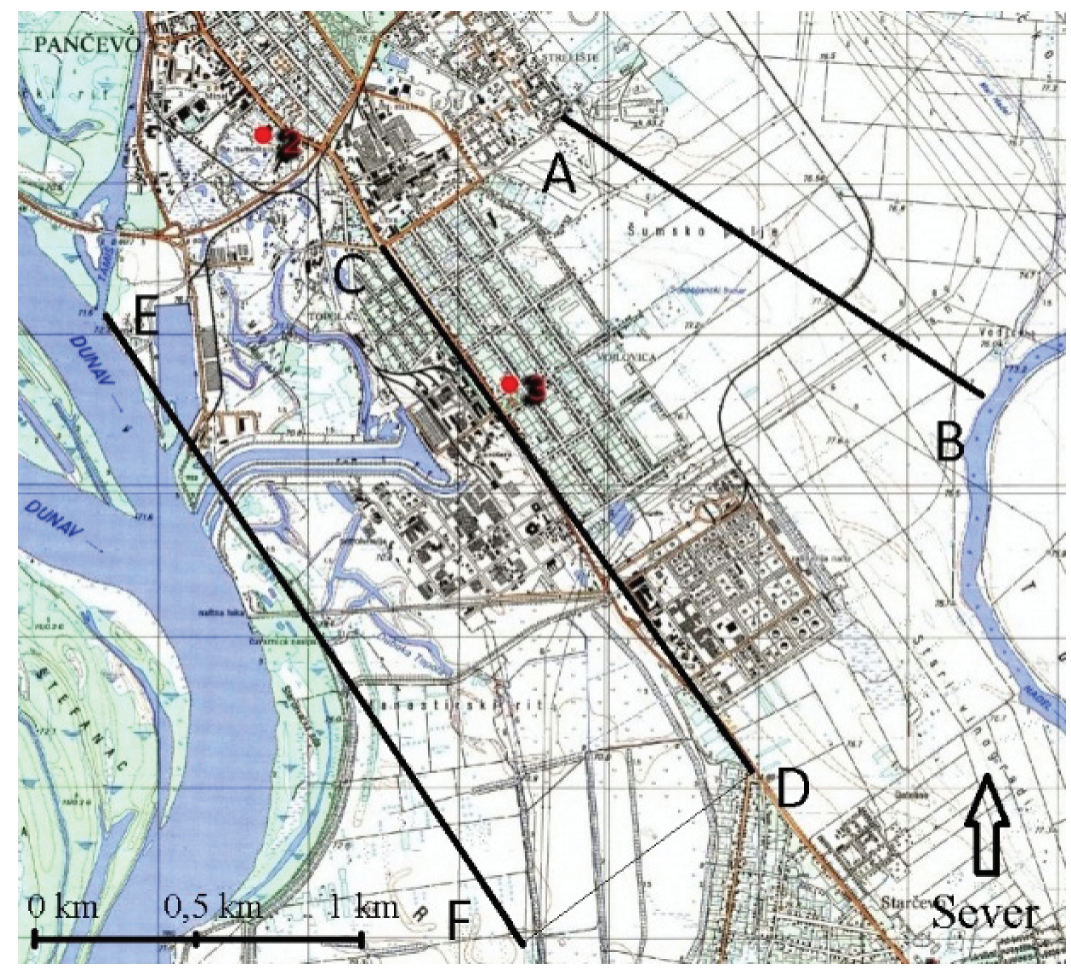

Source: elaborated by the author (2014). 
Nadela). In further processing, the slope of this transect is deliberately sloped to the plane with $C D$ and EF transects due to a better landscape effect. The transect $\mathrm{CD}$ - its beginning (point A) can be located at the junction of today's streets Spoljnostarčevačka and $7^{\text {th }} J u l y$, which has been here for several centuries. Before the colonization, there was a crossroad that determined the end of the Vojlovica forest. The end of the transect (point D) is in Starčevo, also at the historical crossroads in the shape of $\mathrm{Y}$. The transect $\mathrm{EF}$ - point $\mathrm{E}$ is relatively easy to define because it is on the confluence of the rivers Timis and Danube. A bigger problem occurs in the case of the localization of the point $F$. There is no point identifiable in this area on all map materials, therefore, it was determined by the mathematical-cartographic method. The EF transect is parallel to the CD transect, and the point $\mathrm{F}$ is at a right angle to the EFD line.

\section{Framework assessment of individual landscape transects}

Based on the available data, 8 transects and additional transects of the cultural landscape showing the state in the years $4000 \mathrm{BC}$ (approximate time), 1865, 1880, 1882, 1939, 1958, 1995 and 2014 were elaborated.

In the case of the cultural landscape layer showing the state in about $4000 \mathrm{BC}$, data from archaeological excavations that document the existence of Starčevo culture were particularly helpful. Part of the effort is to reconstruct the original vegetation. The segment of the country from 1865 points at the existence of Vojlovica monastery and its homestead. The original settlement of Marienfeld, founded in 1869, was destroyed by the catastrophic flood in 1879. Part of the population settled on the edge of Vojlovica forest, where the village of Vojlovica was later established. In addition to Slovaks, Germans and later Hungarians settled here. The process of change in the landscape can be reconstructed based on landscape segments showing its state in the years 1880 and 1882. The most significant influence of the colonists on the landscape can include cutting down of Voljovica robinia forest and its conversion to built-up areas and arable land. Slovaks dried up Malá slatina (a swamp) and swamps areas around Rít, where they also founded fields, gardens, vineyards and orchards. The territorial extent of the homestead of the monastery in Vojlovica was significantly reduced.

The first years of the establishment of the village until the beginning of World War II is documented in the segment of the country showing the state in 1939. Due to the completion of cultivation of arable land and construction work in the village and around Hora, activity of Vojlovica inhabitants concentrates on the area of Rit, where fields are created, permanent grassland areas are extended and gardens, orchards and vineyards are established. There is also a large 
number of shelters for storing crops, tools, and emergency sleeping - called a cottage. The golden age of the agrarian landscape shows the situation in 1958, shortly before the construction of the first industrial complex in Vojlovica. The local informants also participated in the creation of this part ${ }^{21}$. Based on their testimonies, it was possible not only to reconstruct the landscape but also to record concrete examples of human/society activities in the studied area. For this period, the process of deportation of the German population, the establishment of cooperative farms (zádruga) and the development of a prosperous society of agrarian character is characteristic.

The state of the landscape in 1995 points to the process of industrialization that has been taking place since the 1970s. The factory UTVA-Pančevo producing aircrafts and trucks started operating. A large refinery was also built to produce petrol, diesel, aviation fuel and other oil products. The extensive Azotara and Petrochemical plant was created, the establishment of which was associated with unused crude oil products. There was extensive cultivation work in the Rit area, the entire Danube bed was shifted (many archetypes of the landscape disappear). The original island is turned to the area flooded by the dam, the so-called Vorland. There are also considerable drainage works and the construction of a new river port under the Azotara industrial complex. Due to the construction of the port, Vojlovica beach Čango lida disappears. These changes also affected Slovaks living in the area, who are gradually starting to employ in industrial premises.

The last segment shows the status of the landscape in 2014. The data for this transect were obtained through the field research. The factory UTVA-Pančevo is relocated to Železník, which means it practically disappears from the studied area. A new industrial area was created on this place. In 1999, during a military conflict, refinery and petrochemical plant was damaged by bombs of The North Atlantic Treaty Organisation troops, which partially disrupted its operation.

In 2009, the Russian gas company Gazprom Neft bought the refinery and reconstructed it. The monastery, which is now in the middle of this factory, was returned to the church ownership after the restitution. There are also other businesses in the region, e.g. asphalt production. Overall, we record the stagnation of human activities in the landscape. Gradually, some vineyards and gardens are vacated, some of them being subject to the spontaneous growth of scrub and forest trees.

${ }^{21}$ Oral report of: M. Beracka, born 1936; J. Beracka, born 1943; J. Hríb, born 1955; A. Kuchárikova, born 1938; B. Kulik, born 1986; E. Lenhartova, born 1933; J. Marek, born 1950; J. Marek, born 1974; Otec Dimitrij, J. Pavela, born 1950; J. Spišiak, born 1945; P. Spišiak, born 1948; M. Spišiak, born 1979; E. Spišiaková, born 1978; 2013-2014. 


\section{Map 4}

An example of an elaborated transect of the landscape - an additional transect showing the state of the landscape in 1939
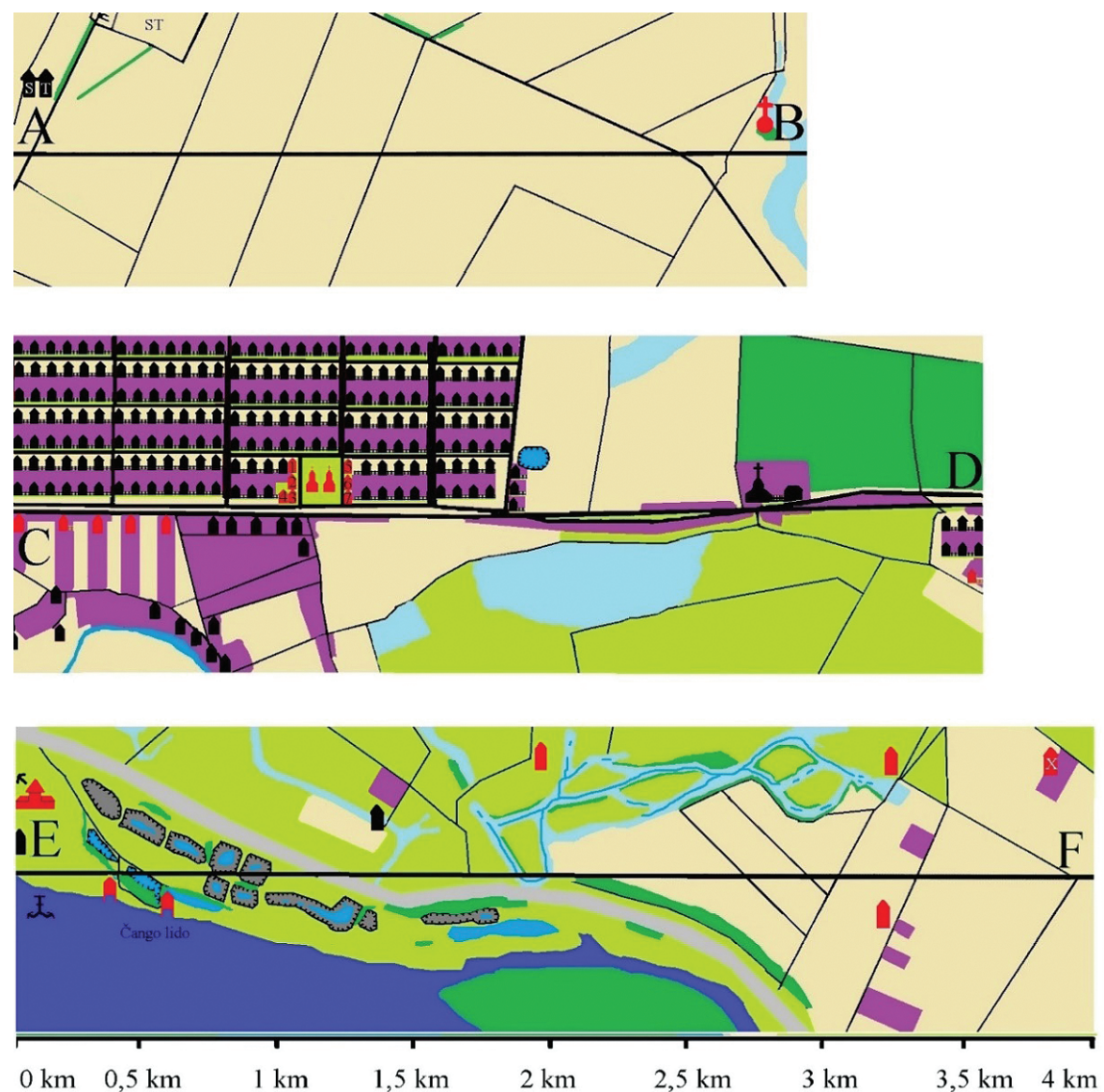

Forested area
Permanent grassland
Wetland per. grassland Surface mining
Water areas
Arable land
Permanent cultures

it Churches

† Chapel Vodice

ธิธี Shooting-gallery

A Svilara

玉n Harbour

A Fisherman's house

- Shed - shelter 


\section{Conclusion - ethnographic and culturological generalizations}

In the studied area, Slovak ethnicity has made a significant contribution to changing the landscape structure. A varied landscape mosaic has been created. The Slovaks moved mainly from the mountainous and foothill areas, where different landscape structure prevailed and it was connected with different technological processes. The first years were, therefore, associated with the experimentation and adaptation of the original Slovak cultural elements in the new cultural landscape. The process of adaptation and domestication lasted probably until the $20^{\text {th }}$ century. The Slovaks brought the development of plant production ${ }^{22}$ and wine-growing to this territory. The proximity of large cities like Pančevo and Belgrade ensured the sale of agricultural products and, hence, the improvement of the living compared to other Slovak enclaves in the Lower Land.

Based on the analysis of the landscape utilization classes, it is obvious that even in the Vojlovica area there is a loss of man's interest in the landscape. Disruption of relationship man/Slovak - the soil is mainly manifested in the overgrowing of arable land with other vegetation and the gradual stagnation and extinction of animal production. Sheep and cattle breeding are also declining. Pig breeding is still popular and it is associated with numerous hog feasts predominantly in autumn and winter. This situation is related, among other things, to the process of globalization and to a change in the way of life and the structure of employment. In the studied area, the third sector employment (services), which is very time-consuming, is increasing today. In the case of the oldest generation (over 80 years old), crafts and agriculture were the most frequent occupations. The middle generation (about 50-60 years old) often worked in factories or as craftsmen and in their leisure time they engaged in agricultural activities. The youngest generation is particularly interested in employment related to the provision of services or, where appropriate, information technology. These jobs are often connected with the need for higher education ${ }^{23}$.

The relationship of the Slovaks to the land can be described as one of the basic characteristics of our nation in the past. The current state is characterized by gradual stagnation. It is doubtful how these factors will affect the persistence or development of Slovak enclaves in Serbia.

${ }^{22}$ Serbian population specialized in animal production. This was based on frequent military conflicts in previous periods. Mobility made a significant contribution to the survival of the local population.

${ }^{23}$ M. Žabenský, Geografia a kultúrno-historický vývoj krajiny, [in:] Vojlovica - kultúrne tradície Slovákov v Banáte, ed. J. Čukan, UKF Nitra, Nitra 2015, pp. 21-78. 
The structure of the landscape and its individual elements often point to the ideological thinking of the individual and society. In research, it is necessary to select elements in the landscape that originated as a creation of an individual, in contrast to the regional or ideological awareness of society ${ }^{24}$. An example is the existence of two evangelical churches in the studied area. One is Hungarian and the other is Slovak ${ }^{25}$. Cultural and ideological differences of the Slovak and Hungarian ethnicities were so different that they contributed to the creation of two of these buildings.

In the past (to a lesser extent nowadays), the landscape and its use have created a certain barrier limiting human activity. Man satisfied his needs in determining a geographical area that limited him to a certain extent, but, at the same time, it provided opportunities to meet his needs. Society needs have an increasing tendency in the process of historical development. After satisfying the basic, i.e. physiological needs, there are the needs, of safety and security, social needs, the need for recognition, and, finally, the need for self-actualization. The basic means of meeting the needs is work, which, at the same time, changes the mind of man and creates values of society. Work and the creation of cultural values in the temporal succession alter the relationship between the natural and cultural landscape (as well as the historical landscape structures). The cultural landscape and its use represent a spatial representation of cultural values that arise from satisfying the needs through work.

\section{Bibliography}

- Babiak M., Anabáza, Vydavatel’stvo Ivan Krasko, Nadlak 2011.

- Bičík I., Jeleček L., Štepánek V., Land-use changes and their social driving forces in Czechia in the $19^{\text {th }}$ and $20^{\text {th }}$ centuries, [in:] Land Use Policy, ed. G.M. Robinson, Oxford, Amsterdam 2001.

- Boltižiar M., Olah B., Krajina a jej štruktúra (Mapovanie, zmeny, hodnotenie), FPV UKF, Nitra 2009.

- Botík J., Etnická história Slovenska, Vydavatel’ské družstvo, Bratislava 2007.

- Čukan J., Dolnozemské reflexie na nerolnícke zamestnania, UKF Nitra, Nitra 2001.

- Čukan J., Kontexty kultúrnych tradicii prímestskej obce v Banáte, „Kontexty kultúry a turizmu", 2014, nr 2.

- Feranec J., Prístupy k analýze viac časových údajov dial'kového prieskumu zeme, „Geografický časopis”, 1996, nr 48.

${ }^{24}$ M. Žabenský, R. Zima, B. Predanocyova, J. Hučková, The Ideological Direction of the Society/Individual in a Specific Historical Period, "European Journal of Science and Theology", 2016, no 12, pp. 230.

${ }^{25}$ Originally, German-Slovak. 
- Chrastina P., Výskum krajiny (z aspektu historickej geografie a krajinnej archeológie), „Geografické štúdie”, 2010, nr 14.

- Chrastina P., Profily kultúrnokrajinných vrstiev - metóda výskumu nielen industriálnej krajiny: na príklade mesta Nováky, „Historická geografie”, 2011, nr 37.

- Kurpaš M., Transformácie tradičnej architektúry, [in:] Silbaš - kultúrne tradície Slovákov v Báčke, ed. J. Čukan, Ústav pre kultúru vojvodinských Slovákov, Nový Sad 2013.

- Michalík B., Spolková činnost', [in:] Pivnica - kultúrne tradície Slovákov v Báčke, ed. J. Cukan, Slovenské vydavatel’ské centrum, Báčsky Petrovec 2010.

- Michalík B., Akulturačné procesy v prostredí dolnozemských Slovákov, Vydavatel'stvo Ivan Krasko, Nadlak 2015.

- Muchová Z., The potential of the landscape with dispersed settlement (case study Čadca town), [in:] Public recreation and landscape protection - with man hand in hand, ed. J. Fialková, D. Pernicová, Mendelova univerzita, Brno 2013.

- Otahel' J., Krajinná pokrývka Slovenska, VEDA, Bratislava 2001.

- Otahel' J., Feranec, J., Výskum zmien krajinnej pokrývky pre poznanie vývoja krajiny, „Geographia Slovaca”, 1995, nr 10.

- Otahel' J., Feranec T., Cebecauer T., Pravda J., Husár K., Krajinná štruktúra v okrese Skalica: Hodnotenie zmien, diverzity a stability, „Geographia Slovaca”, 2004, nr 19.

- Petrovič F., Vývoj krajiny v oblasti štálového osídlenia Pohronského Inovca a Tribeča, SAV, Bratislava 2005.

- Pucherová Z., Vývoj využitia krajiny na rozhraní Zobora a Žitavskej pahorkatiny, UKF Nitra, Nitra 2004.

- Sklabinská M., Mosnáková K., Slováci v Srbsku z aspektu kultúry, Štamparija Stojkov, Nový Sad 2012.

- Žabenský M., Geografia a kultúrno-historický vývoj krajiny, [in:] Vojlovica - kultúrne tradície Slovákov v Banáte, ed. J. Čukan, UKF Nitra, Nitra 2015.

- Žabenský M., Zima R., Predanocyova B., Hučková J., The Ideological Direction of the Society/Individual in a Specific Historical Period, "European Journal of Science and Theology", 2016, no 12.

\section{Informants}

- Beracka M., born 1936

- Beracka J., born 1943

- Hríb J., born 1955

- Kuchárikova A., maiden name Brezinová, born 1938

- Kulik B., born 1986

- Lenhartova E., born 1933

- Marek J., born 1950

- Marek J., born 1974

- Pavela J., born 1950

- Spišiak J., born 1945

- Spišiak P., born 1948

- Spišiak M., born 1979

- Spišiaková E., maiden name Beracková, born 1978 
Summary: Using an example of cultural landscape research in the village of Vojlovica through a multitemporal analysis of cultural landscape layer transects, several generalizations of ethnographic, cultural and historical character could be formulated. Cultural landscapes leave behind traces (cultural landscape layers) that mirror the relationship of culture and society on a given territory. The research was focused predominantly on the $19^{\text {th }}$ and $20^{\text {th }}$ centuries. During this period colonization and establishment of Vojlovica village took place. Subsequently, the development of agriculture took place, which gave the country agricultural character. After World War II, industrialisation takes place, which also changes the culture of local people. In recent years, we can notice a more significant impact of globalization, with an emphasis on thinking of an individual/ society in the context of a new cultural development of society.

Keywords: cultural landscape, Lower Land, Slovaks in Serbia, Vojlovica, colonization

\section{Słowacy w Serbii - badania dokonane w miejscowości Vojlovica za pomocą wieloczasowej analizy warstw krajobrazu kulturowego}

Streszczenie: Analiza transektów warstw krajobrazu kulturowego miejscowości Vojlovica, stanowiąca przykład badania krajobrazu kulturowego, umożliwiła sformułowanie szeregu uogólnień o charakterze etnograficznym, kulturowym i historycznym. Krajobrazy kulturowe pozostawiają ślady odzwierciedlające pewien związek między kulturą a społeczeństwem zamieszkującym dany obszar. Badanie koncentruje się głównie na XIX i XX wieku, kiedy to miało miejsce osadnictwo i powstanie miejscowości. Następnie nastąpił rozwój rolnictwa, co nadało miejscu charakter rolniczy. Po drugiej wojnie światowej następuje industrializacja, która ma również wpływ na kulturę miejscowej ludności. W ostatnich latach daje się zauważyć znaczący wpływ globalizacji, z naciskiem na myślenie o jednostce/społeczeństwie w kontekście nowego rozwoju kulturowego społeczności.

Słowa kluczowe: krajobraz kulturowy, Dolne Ziemie, Słowacy w Serbii, osadnictwo 